\title{
ÇOCUĞA YÖNELIK CINSEL ISTISMARLA MÜCADELEDE : ÇOCUK IZLEM MERKEZI
}

\section{FIGTING SEXUAL ABUSE AGAINIST CHILDREN: CHILD FALLOW UP CENTER}

\author{
İshak AYDEMIR ${ }^{1}$ \\ Fayik YURTKULU ${ }^{2}$
}

\section{ÖZET}

Çocuklara yönelik cinsel istismar, insanlığın varoluşundan beri ortaya çıkan ve günümüzde de devam eden çok önemli ve müdahale gerektiren bir sosyal sorundur. Istismar mağduru çocukların tespiti noktasında toplumsal, kültürel, geleneksel engeller bulunmakta ve tespit noktasında rol alan profesyoneller veya kurumların tutumu da en önemli etkenlerdendir. Günümüzde, bilimsel ve teknolojik gelişmeler, kitle iletişim araçlarının hızlı yaygınlaşması, toplumun eğitim seviyesinin yükselmesi sayesinde sağlık çalışanlarının, kolluk kuvvetlerinin ve toplumun çocuğa yönelik cinsel istismar konusunda farkındalık düzeyleri artmıştır. Bu durum, cinsel istismar mağdurlarının tespiti, tıbbi, psikolojik ve sosyal yönden müdahale çalışmalarının hızlanmasına katkı sağlamıştır. Çocuklara yönelik cinsel istismar ile mücadele kapsamında Sağlık, Adalet, İçişleri, Milli Eğitim Bakanlıkları, Adli Tıp Kurumu, (Mülga) SHÇEK ${ }^{3}$ ve üniversitelerin çocuk birimlerinin yürüttüğü eş güdümlü çalışmaların sonucunda Kasım 2010 tarihinde resmi açılışı yapılmış ve Çocuk İlem Merkezi (ÇiM) Sağlık Bakanlığı'na bağıı Ankara Dışkapı Çocuk Sağlığı ve Hastalıkları Onkoloji Hematoloji Eğitim ve Araştırma Hastanesi bünyesinde kurulmuştur. Bu makalede çocuk istismarının önlenmesi ve istismara uğrayan çocuklara müdahale edilmesi amacıyla oluşturulan Çocuk İlem Merkezinin kuruluşu, işleyişi ve çocuklara bilinçli ve etkin bir sosyal hizmet müdahalesi verme konuları incelenmiştir.

Anahtar Kelimeler: Çocuk Koruma Birimi, Adli Görüşme, Sosyal Hizmet Müdahalesi.

\footnotetext{
${ }^{1}$ Yrd. Doç. Dr. Turgut Özal Üniversitesi Sağlık Yüksek Okulu Sosyal Hizmet Bölümü, e-posta: ishak72@gmail.com

${ }^{2}$ Sosyal Hizmet Uzmanı, Çocuk İzlem Merkezi. e- posta: shufyurtkulu@gmail.com

${ }^{3} 633$ Sayılı KHK ile Sosyal Hizmetler ve Çocuk Esirgeme Kurumu Kapatılarak Aile ve Sosyal Politikalar Bakanlığı kurularak SHÇEK yerine Çocuk Hizmetleri Genel Müdürlüğü de kurulmuştur.
} 


\section{ABSTRACT}

Sexual abuse against children is a social problem which is very important and necessary to stop from existence of humankind to nowadays. There are some social, culturel and traditional impediments for determinations of sexual abuse children. Moreover the other most important factor is professionals' and foundations 'attitudes for determinations of its. Nowadays, medical, psychological and social studies accelerated because of at the point of determination of sexual abuse against children. Reasons for scientific and tecnological developments, to become widespread rapidly of mass media, advanced of the level of social's educations, healthy employees and law enforcement agencies and another interested in individuals become unconscious. About struggling of sexual abuse intended to children, at the end of the coordinated studies with Ministries of Healthy, Justice, Internal Affairs and Education, (cancelled) SHÇEK (Social Work and Society For Protection of Children) and children units of universities, in 2011 child protect center had been established in Ankara Dışkapı Child Health and IIIness Pediatric Hematology and Oncology Education Research Hospital connected to Ministry of Healthy. This article is about teorical knowledge of sexual abuse of children, the foundation, introduction, process procedure of child protect center and social work intervention.

Key Words: Child protection unit, judicial interview, social work intervention.

\section{GiRiş}

Son yıllarda çocuğa karşı cinsel istismar vakalarındaki artış nedeniyle istismar mağdurlarını değerlendirmek, tedavi etmek ve izlemek için üniversite hastanelerinde oluşturulan "Çocuk Koruma Birimi” gibi birimlerin Sağlık Bakanlığı'na bağlı hastanelerde de multidisipliner bir yaklaşımla kurulmaya başlanması önemli bir gelişmedir.

Çocuklara yönelik cinsel istismar ile mücadele kapsamında Sağlık, Adalet, İçişleri, Milli Eğitim Bakanlıkları, Adli Tıp Kurumu, SHÇEK ve üniversitelerin çocuk birimlerinin yürüttüğü eş güdümlü çalışmaların sonucunda Çocuk İzlem Merkezi kurulmuştur. Protokol çerçevesinde pilot il olarak Ankara'da Sağlık Bakanlığı'na bağlı Dışkapı Çocuk Sağlığı ve Hastalıkları Onkoloji Hematoloji Eğitim ve Araştırma Hastanesi bünyesinde Kasım 2010 tarihinde kurulmuştur. Kurumun fiziksel altyapısının yetersiz olması nedeniyle sonraki dönemlerde Sami Ulus Kadın Doğum, Çocuk Sağığı ve Hastalıkları Eğitim ve Araştırma Hastanesine bağlı olarak Yenimahalle Devlet 
Hastanesi bünyesinde bulunan binaya taşınmış olup bu binada hizmet vermektedir. Çocuklara yönelik cinsel istismar ile mücadele kapsamında Çocuk İzlem Merkezinin kurulmuş olması çok önemli bir adımdır. Bu makalede çocuk cinsel istismarına ilişkin teorik bilgi, Çocuk İzlem Merkezinin kuruluşu, tanıtımı, işleyiş prosedürü ve sosyal hizmet müdahalesi ele alınmıştır.

\section{ÇOCUK CINSEL ISTISMARI}

Çocuğun cinsel istismarı, çocuğun tam olarak kavrayamadığı, gelişimsel olarak henüz hazır olmadığı, rıza gösterme ve onaylama kapasitesine sahip olmadığı, sosyal yönden ve yasalar tarafından yasaklanan ve suç sayılan cinsel bir aktiviteye zorlanmasıdır (Yurdakök, 2010).

Bir çocuk ile bir yetişkin veya başka bir çocuk arasında, cinsel gereksinimleri tatmin etmeyi amaçlayan her türlü eylem ve hareketler çocuğun cinsel yönden istismarıdır. Çocuğun cinsel haz amaçlı kullanıldığı her türlü eylem ve hareketler, cinsel istismar kapsamında olup fiziksel temas, vajinal, oral, anal penetrasyon, fiziksel temas içermeyen cinsel içerikli konuşma, izleme, cinsel organları gösterme, pornografik içerikli materyalleri izlettirme gibi farklı şekillerdeki cinsel aktiviteyi içermektedir (Butcahart and Harvey, 2006; Dağlı ve İnanıcı, 2010).

\section{Cinsel İstismar İçin Risk Faktörleri}

Cinsel istismar, farklı alanlardaki çoklu faktörlerin etkileşiminin sonucu olarak karşımıza çıkmaktadır. Cinsel istismara neden olan risk faktörleri, kişisel, ilişkisel, çevresel ve toplumsal düzeyde incelenebilir (Canat, 1994; Ferguson vd. 1997; Green, 1996; Kerimoğlu ve Avcı, 1991; Polat, 2006; Putnam, 2003; Smith and Bentovim, 1994; Taner ve Gökler, 2004; Yurdakök, 2010).

Çocukken cinsel istismara maruz kalmış olmak, fiziksel veya psikiyatrik bir hastalığı olmak, dürtü ve öfke kontrolünün yetersizliği, toplumsal iletişim becerisinin yetersizliği, alkol ve madde bağımlısı olmak, genç ebeveyn olmak, yalnız yaşayan ebeveyn olmak, çocuk gelişimi hakkında bilgisizlik ve bilinçsizlik anne, baba veya bakım veren kişilerle ilişkili risk faktörleri arasında sıralanabilir.

Çocuğa karşı cinsel istismar, anne, baba, çocuğun kendisinden büyük arkadaşı, kardeşi, üvey ebeveynler, komşu, öğretmen, tanıdık diğer kişiler veya herhangi tanıdık olmayan bir yabancı tarafından yapılmaktadır. Genel kanının aksine, cinsel istismar aile dışındaki 
yabancılardan çok, aile içi bir yetişkin veya çocuğun tanıdığı bir birey tarafından yapıldığı belirtilmektedir. Şöyle ki, istismar edenlerin \% 31'i aile içinden, \% 54'ü aile dışından ancak çocuğun tanıdığı bir kişi tarafından ve sadece $\% \quad 15 \mathrm{i}$ yabancı biri tarafından gerçekleştirilmektedir.

İlişkisel risk faktörleri arasında ebeveyn ve çocuğun bağının kopuk olması ve bağın kurulamaması, çok çocuklu ve katı disiplin uygulayan bir aile yapısı, işsizlik, ekonomik sorunlar, aile içi şiddetin varlığı, sosyal destek sistemlerin zayıf ve yetersizliği, aile bireyleri arasındaki bağın zayıf olması, sözel ve psikolojik çatışmaların, tartışmaların sık yaşanması yer almaktadır.

Çevresel risk faktörleri uyuşturucu ticaretinin varlığı ve erişiminin kolay olması, yetersiz beslenme, barınma ve bakım şartları, işsizlik oranının yüksek olması, çocuğun savunuculuğunu yapacak kurum ve yapıların yetersizliği ve çocuk işçiliği konusunda denetleme ve rehabilitasyon yetersizliği sayılabilir.

Toplumsal risk faktörleri, çocuğu koruyan yasaların yetersizliği, çocuğa verilen değerin düşük olması, cinsel ayrımcılık ve toplumsal eşitsizlik, şiddetin kabul edilir olması, organize şiddetin varlığı (savaş, terör, yüksek suç oranları), pedofili ve kontrolsüz internet kullanımı sayılabilir.

Hiçbir faktör tek başına çocuğa karşı cinsel istismarın nedenini açıklamak için yeterli olmaz. Cinsel istismar, farklı alanlardaki çoklu faktörlerin karmaşık etkileşiminin sonucu olarak ortaya çıkabilmektedir. Risk faktörü olarak kabul edilen durumların varlığı, cinsel istismarın varlığını kesin olarak göstermez ve tanıyı sağlayamaz.

Cinsel istismara uğrayan çocuklarda korku reaksiyonu, depresyon, anksiyete, kızgınlık, düşmanlık, post-travmatik stres bozukluğu, uygunsuz cinsel davranışlar (herkesin ortasında mastürbasyon, cinsel ilişki taklidi, anüs veya vajinaya cisim sokmak, insanlara sürtünmek ve sürekli genital organlarıyla oynamak gibi) gibi duygusal ve davranışsal etkiler görülebilmektedir (Browne ve Finkelhor, 1986; Kendall Tackett vd, 1993). Cinselliğe ilişkin her türlü konu ve duruma aşırı ilgi gösterme ya da aşırı kaçınma, baştan çıkarıcı davranışlar, çok sık öpmeye çalışma, göğüslere, bacaklara ya da genital bölgeye dokunmaya çalışma, sürtünme, kendi genital bölgesini gösterme, bedeninin kirli ya da zedelenmiş olduğuna inanma ve ifade gibi davranış özellikleri daha çok cinsel istismarı akla getirir. Ancak bu davranışların cinsel istismar için kesin belirtiler 
olmadığı, çocukların farklı sebeplerle de böyle davranabileceği bilinmelidir. Genital bölgesinde bir sorun olduğundan korkma, resimlerinde, oyunlarında ya da hayallerinde cinsel istismara uğradığını düşündürecek özelliklerin bulunması tuvalet eğitimini kazanmış bir çocuğun altını veya yatağı ıslatmaya başlaması, regresif semptomların varlığı (kendine zarar verici davranışlar, bebeklik davranışları, bebek gibi konuşma) gibi belirtilerin hiçbiri cinsel istismarın kesin ve net göstergesi değildir. Çocuklar farklı nedenlerle de böyle davranabilir ve patolojik değişiklikler gösterebilirler. Ancak, bu belirtilerin fark edilmesi halinde cinsel istismar olasılığını da düşünmek gerekir (Ekşi, 1999; Hancı, 2002; Kara vd. 2004; Kurtay, 2004; Taner ve Gökler, 2004).

\section{Çocuk Cinsel İstismarı ile Mücadele Kapsamında Çocuk Koruma Birimleri}

Ülkemizde sağlık alanında ekiple çalışma anlayışı yeterince yerleşmemiş olduğu için cinsel istismara uğrayan bir çocuk hastaneye getirildiğinde veya başvurduğunda poliklinikler ve servisler arasında pingpong topu gibi dolaşmaktadır. Hastaneye ilk başvuruda karşılaştığı hekim genellikle bu konuda uzmanlığı olmayan biri olmakta, ilk öykü ve muayene sıklıkla acil ya da poliklinik gibi hastanenin en kalabalık ve yoğun bölümlerinde çocuğun değerlendirilmesi için uygun olmayan koşullarda yapılmaktadır. Daha sonra hasta, gerekiyorsa ilgili birimlere yönlendirilmekte, buralarda öykü ve fizik muayene tekrar tekrar yapılmaktadır. Ayrıca bazı bölümlerden randevu alınmasının zorlukları, bazen randevuların ileri tarihlere verilmesi gibi problemlerle de karşılaşılmaktadır. Bu süreç çocuk için oldukça örseleyici olup genellikle olay bu kadarla da kalmaz. Resmi yazı için çocuğun bir kez de adli tıp kurumunda muayene edilmesi istenmektedir. Ayrıca soruşturma sürecinde mağdur çocuğun ifadesi alınırken ve mahkeme sürecinde hakim ve savcıların bu konuda bilgi düzeylerinin yetersiz olması nedeniyle çocuk aynı sorulara tekrar tekrar maruz kalabilmektedir. Bu ortamlar, çocuğun ikincil örselenmesine katkıda bulunur. İstismar olgularına en uygun tedavi ve izlem yaklaşımı çok merkezli bir ekip çalışması ile sağlanabilir. Bu kapsamda son yıllarda ülkemizde tıp alanında konuya ilgi ve duyarlılık artmış, hastanelerde çocuk koruma birimleri oluşturulmaya başlamıştır. Ankara'da Gazi Üniversitesi bünyesinde kurulmuş olan "Çocuk Koruma Merkezi" resmi olarak oluşturulmuş ilk merkezdir. Ankara, İstanbul, İzmir, Adana, Kayseri, Antalya, Samsun, Düzce, Aydın, Kocaeli gibi pek çok ilde üniversitelerin bünyesinde ya 
da eğitim hastanelerinde bu amaçla çalışan çocuk koruma birimleri kurulmuştur (Beyazova ve Şahin, 2007).

Son yıllarda medyanın çocuk ihmal ve istismarı konusuna duyarlı yaklaşımı sayesinde toplumda çocuğa yönelik davranışlar dikkat çekmiş ve ilgi uyandırmıştır. Sağlık personeli dahil olmak üzere ilgili uzmanların meslek içi eğitimlerinin yapılmasına, çocuk koruma birimlerinin hızla yayılmasına katkı sağlamıştır. 2010 yılında çocuklara yönelik cinsel istismar ile mücadele kapsamında Sağlık, Adalet, İçişleri, Milli Eğitim ile Aile ve Sosyal Politikalar bakanlıkları, Adli Tıp Kurumu ve üniversitelerin çocuk birimlerinin yürüttüğü eş güdümlü çalışmaların sonucunda Sağlık Bakanlığı'na bağlı ilk Çocuk İzlem Merkezi kurulmuştur.

\section{ÇOCUK IZLEM MERKEZi}

Çocuk İzlem Merkezi, cinsel istismar şüphesi olan çocuğun beyanının çocuk dostu bir ortamda alınmasının ardından adli ve tıbbi muayenesi sosyal hizmet desteği ve aile danışmanlığı verilerek adli mercilere gereken raporların hazırlandığı bir merkezdir. Çocuk İzlem Merkezinin amaçları;

1. Cinsel istismara uğrayan çocuğa inceleme ve tedavi aşamasında gerek görülen sağlık, eğitim, kolluk kuvvetleri, hukuk ve adalet sistemi gibi işbirliği yapılması gereken diğer kamu kuruluşları ile eşgüdüm içinde hizmet sağlanması,

2. Güvenli ve çocuk dostu ortam ile çocuktaki travmanın etkilerinin azaltıması, korunma altına alınması gereken olgularda, çocuğun kalabileceği uygun bir ortam sağlanıncaya kadar geçici bir süre barınma, beslenme, giyim, sağlık ve güvenlik gereksinimlerinin karşılanması,

3. Ailenin yaşadığı travmanın ve yaşanan olayın sağlıklı değerlendirilmesi amacıyla aile ile görüşülmesi,

4. Ailenin ilk danışmanlık gereksinimlerinin karşılanması şeklinde kısaca sıralanabilir.

Bu amaçla, Sağlık Bakanlığı tarafından çocuk ihmal ve istismarını önlemeye yönelik eğitici eğitimleri planlanıp gerçekleştirilmiştir. Daha sonra eğitici eğitimine katılan eğitimciler kurumlarındaki çocuk servisi ile acil serviste çalışan tüm ebe, hemşire, doktor, sağlık memuru, acil tıp teknisyenleri, fizyoterapistler, sosyal hizmet uzmanları, psikolog ve çocuk gelişim uzmanlarına çocuk inmal ve istismarını önlemeye yönelik eğitim vermiştir. Bu eğitimlerin hedefi, çocuk istismarının 
tanımını yapabilmek, çocuk istismarının boyutunu ve önemini kavramak, istismara uğrayan çocuğu fark edebilmek, cinsel istismara uğradığı fark edilen, öğrenilen ya da cinsel istismar şüphesi uyandıran çocuklara Çocuk İzlem Merkezinin kuruluş felsefesine uygun yaklaşımda bulunmak, bu çocukların Çocuk İzlem Merkezine uygun şekilde ulaşmasını sağlamak ve diğer istismar ve ihmal olgularında doğru yaklaşımda bulunmaktır.

\section{Çocuk İzlem Merkezinin İşleyiş Prosedürü}

Çocuk İzlem Merkezi, 24 saat hizmet sunumunu esas alan bir kurumdur. Kurumda, adli tıp uzmanı, sosyal hizmet uzmanı, psikolog, Aile ve Sosyal Politikalar Bakanlığı'nı temsilen bir sosyal hizmet uzmanı ve hemşire çalışmaktadır. Adliyeden görevlendirilen bir Cumhuriyet Savcısı ve CMK tarafından görevlendirilen bir avukat da her gün adli görüşme için kurumda hazır bulunmaktadır.

Çocuk İzlem Merkezlerinde görüşmelerin ses ve görüntü kaydının yapıldığı ve cumhuriyet savcısı, adli tıp uzmanı, pediatrist, çocuk psikiyatristi, sosyal hizmet uzmanı, psikolog ve çocuğun avukatının görüşmeyi isteyebileceği özel tasarlanmış aynalı oda mevcuttur.

Çocuk İzlem Merkezine kolluk kuvvetlerine, hastanelere doğrudan yapılan veya ihbar gelmesi durumunda konu çocuk izleme merkezi'nde görev yapan Cumhuriyet Savcısı'na bildirilir. Daha sonra Cumhuriyet savcısının talimatıyla kolluk kuvvetlerinin bu iş için özel eğitim almış sivil personeli, çocuğu bulunduğu yerden sivil bir araçla alarak merkeze getirmektedir. İstismar edildiği bilinen ya da kuşkulanılan çocukla kolluk birimlerinde olaya-ilişkin bir görüşme yapılmaz. Mağdur, Çocuk İzlem Merkezine sivil ekiple ve sivil araçla, olay hakkında herhangi bir görüşme yapmadan nakledilir. Bu arada barodan çocuk için avukat ataması yapılır.

Çocuk İzlem Merkezine getirilen bir vaka ile öncelikli olarak ön görüşme, ardından adli görüşme, tıbbi muayene ve psikiyatrik işlemleri gerçekleştirilmektedir. Genellikle psikolog, çocukla; sosyal hizmet uzmanı aile ile ön görüşme yapmaktadır. Aile ve çocukla ilk görüşmede psiko-sosyal öykünün alınması, görüşme kayıtlarının tutulması, rapor hazırlanması işlemleri yürütülmektedir. Gerektiğinde telefonla, zaman zaman ev, okul ya da çocuğun barındığı kurumlara ziyaretlerle olguların süreç boyunca izlemi sosyal hizmet uzmanı ve psikolog tarafından birlikte yürütülmektedir. Bu süreçte sosyal hizmet uzmanı, aile görüşmesi yaparak, ailenin yapısını, dinamiklerini, sosyo-ekonomik durumunu, ilişkilerini sosyal hizmet mesleğinin genel yaklaşımı çerçevesinde inceler ve değerlendirir. 
Mağdur ile yapılan ön görüşme neticesinde cinsel istismara uğradığı şüphesine varılması halinde, herhangi bir adli veya psikiyatrik muayene yapılmadan durum derhal nöbetçi Cumhuriyet Savcısına bildirilecek ve alınacak talimata göre hareket edilmektedir.

Mağdur ile yapılan ön görüşme neticesinde cinsel istismara uğradığı şüphesi oluşmaması durumunda ilgili branşlardan (adli tıp uzmanı, çocuk cerrahisi, çocuk psikiyatrisi gibi) konsültasyon talep edilerek, sadece tıbbi süreç başlatılacak, bu sürecin sonunda istismar şüphesinin oluşması durumunda ise nöbetçi Cumhuriyet savcısı bilgilendirilerek alınacak talimata göre hareket edilmektedir.

Cumhuriyet savcısının emir ve talimatları doğrultusunda, mağdur çocuğun beyanının alınmasını müteakip, ilgili mevzuatında öngörüldüğü şekilde Çocuk İzlem Merkezinde mağdurun veya velisinin rızası alınarak vücudu üzerinde dış veya iç beden muayenesi yapılacak, vücudundan örnek alınması, psikiyatrik muayenesinin gerçekleştirilmesi ve gerektiğinde fizikî bulguların görüntülerinin kaydedilmesi sağlanmaktadır (Çocuk İlem Merkezi Koordinasyon Kurulu Kararı, 2012).

Mağdur çocuğun beyanı ilgili mevzuatına uygun olarak; Cumhuriyet Savcısı ya da zorunlu hallerde Cumhuriyet Savcısının emir ve talimatı doğrultusunda kolluk görevlisi tarafından, vekili huzurunda, merkezde görevli ve bu konuda eğitim almış uzman bir kişi vasıtasıyla, aynalı bir odada, ses ve görüntü kaydı yapılmak suretiyle alınmaktadır (Çocuk İzlem Merkezi Koordinasyon Kurulu Kararı, 2012).

Adli tıp uzmanı, çocuk psikiyatristi ve çocuk hekimi tarafından cinsel istismar şüphesi olan çocuğun vücudunun tümü (cinsel organlar dahil olmak üzere) detaylıca muayeneden geçirildikten sonra fiziki bulgular kaydedilmektedir.

Görüşme ve muayeneler tamamlandıktan sonra elde edilen tüm bilgi ve belgeler bir rapor haline getirilerek, ses ve görüntü kayıtları ile birlikte ilgili Cumhuriyet Başsavcılığına gönderilmektedir. Bu rapor doğrultusunda işlem yapılır. Cinsel istismarın varlığını kanıtlayan deliller mevcut ise savcılık, ilgili failler hakkında TCK (5237 Sayılı Türk Ceza Kanunu, 2005)'ya göre soruşturma başlatır. Adli görüşme ve muayene sürecinde çocuğun kısa süreli koruma ve tedavi tedbiri bu merkezde yürütülür. Çocuk tedavi ve rehabilitasyon amacıyla uzun erimli tedavi ve izlem planı için Çocuk İlem Merkezinde görev yapan Aile ve Sosyal Politikalar Bakanlığı temsilcisi olan sosyal hizmet 
uzmanı tarafından uygun merkeze yönlendirilerek yerleştirilmesi sağlanır.

Sağlık çalışanlarının (psikiyatrist, psikolog, sosyal hizmet uzmanı, çocuk gelişim uzmanları, diğer hekimler, hemşireler, acil servis ve çocuk servis çalışanları gibi) cinsel istismar konusunda bilgilendirilmesi halinde cinsel istismar vakalarının bildiriminde de önemli bir artış olacağı ve mağdur çocuklara uygun ve güvenilir bir ortamda tıbbi ve psiko-sosyal yardım ve destek sağlanmış olacağı düşünülmektedir. Bu amaçla cinsel istismar olgularının en hızlı, doğru ve tek seferde değerlendirilmesi için her sağlık kuruluşunda çocuk istismar ve ihmal ekiplerinin kurulması gerekmektedir.

$\mathrm{Bu}$ amaçla kurulan Çocuk İzlem Merkezi, çocuğun yaşadıklarını tekrar tekrar dile getirmesini ve muayene edilmesini önleyerek adli süreçte yaşayabileceği travmayı en aza indirmeyi amaçlayan bir özelliğe sahiptir. Üniversitelerin çocuk koruma merkezleri özerk yapıları nedeniyle devlet kurumlarını bir araya getirmede sorun yaşadığı için Çocuk İzlem Merkezi modelinin oluşturulması intiyacı ortaya çıkmıştır.

Çocuğun cinsel istismarı kavramı, sosyal hizmetin temel alanlarından "Aile ve Çocuk Refahı" içerisinde ele alınmaktadır. Aile sorunlarının çözülmesi, ailenin düzenli bir şekilde gelişmesi ve devam etmesi amacını güden çalışmalar sosyal hizmetin "Aile Refahı" alanını oluşturur. Aile refahı ile birlikte düşünülen "Çocuk Refahı" alanı da önemli hizmetleri içerir. Çocukların refahına etki eden her husus aynı zamanda çocuğun üyesi bulunduğu bütün grupların, ailenin ve toplumun refahı ile ilgilidir (Koşar, 1989).

\section{ÇOCUK IZLEM MERKEZLERINDE SOSYAL HIZMET UYGULAMALARI}

Çocuk İzlem Merkezinde çalışan sosyal hizmet uzmanları (Sağlık Bakanlığı ve Aile ve Sosyal Politikalar Bakanlığı personeli), koruma getirilen istismar mağduru çocuğun ailesi ile ön görüşme yaparak mesleki müdahale sürecini başlatır. Sosyal hizmet uzmanı, genelci sosyal hizmet yaklaşımı doğrultusunda aile ve çocuk ile mikro, mezzo ve makro düzeyde mesleki müdahaleyi planlar ve gerçekleştirir.

Cinsel istismar mağduru çocukla görüşme yapmak, değerlendirme sürecinin en kritik ve önemli adımıdır. Sosyal hizmet uzmanı, çocuk ve cinsel istismar ile ilgili çocukla görüşme konusunda donanımlı ve eğitimli olmalıdır. Görüşme yapmak bilgi, beceri ve deneyim isteyen karmaşık bir süreçtir. Sosyal hizmet uzmanı, konusunda yeterli bilgi, 
beceri ve deneyime sahip olan, empatik, sabırlı, yargısız, çocuğu destekleyici, güven verici ve mahremiyete saygı duyan bir yapıya sahip olmalıdır.

Sosyal hizmet uzmanı, çocuğun ve ailesinin ayrıntılı psiko-sosyal değerlendirmesini yapar. Sosyal hizmet uzmanı bu kapsamda, çocuk ve ailesinin sosyo-demografik özellikleri, güçlü ve zayıf yönleri, sosyal destek sistemlerini, risk faktörleri, ailenin ekonomik durumu, dinamikleri, çocuğun bilişsel, fiziksel, duygusal ve sosyal gelişim düzeyi gibi konularda ayrıntılı bir inceleme yapar.

Şüpheli vakalarda dikkat edilmesi gereken önemli bir nokta çocuk ve aileye ilişkin risk faktörlerinin değerlendirilmesidir. Cinsel istismar mağduru çocuk, aile bireylerinden biri tarafından istismar edilmiş ise çocuğun güvenli bir ortamda yaşaması için ailesinden ayrılması ve korunması gerekebilir. Bu acil durumda, çocuğun korunabileceği ve barınabileceği uygun bir korunma yöntemi ve kurumu seçilmelidir. Sosyal hizmet uzmanı, Çocuk Koruma Kanunu (5395 sayılı kanun, 2005) kapsamında acil korunma kararı alınması yönünde Cumhuriyet Savcısı ile değerlendirme yapar. Acil durumlarda Cumhuriyet Savcısı'nın kararıyla koruma kararı alınarak yaşına uygun bir kuruma yerleştirilmesi sağlanır. Acil durumlar dışındaki vakalarda korunma kararının alınması yönünde sosyal inceleme raporu hazırlar ve mahkeme kararı ile korunmasını talep eder. Mahkeme kararı çıkana kadar, çocuğun kurumda geçici olarak kalması sağlanır ve Aile ve Sosyal Politikalar Bakanlığı'na bağlı uygun bir kuruma yerleştirilir. Mahkeme, mağdur ve/veya aile hakkında hazırlanan sosyal inceleme raporu doğrultusunda sağlık, barınma, eğitim, bakım veya danışmanlık tedbirlerinden biri veya birkaçına karar verebilir.

Ancak ailede çocuğu koruyacak ve çocuğa güvenli bir ortam sağlayacak başka aile üyeleri mevcutsa çocuğun aileden ayrılması gerekmeyebilir. Bu durumda, sosyal hizmet uzmanı ve gerekiyorsa diğer profesyoneller aileyi psiko-sosyal yönden destekler.

Sosyal hizmet uzmanı, sosyal inceleme raporu hazırlarken gerekli durumlarda cinsel istismar mağduru çocuğun okulunu ziyaret eder. Okul rehberlik öğretmenleriyle ve / veya doğrudan mağdurun öğretmeni ile durumu hakkında bilgi edinir ve işbirliği içinde mağdurun tedaviden etkin bir şekilde yararlanması desteklenir. Bu süreçte cinsel istismar mağduru çocuğun afişe edilmeden, mahremiyetinin sağlanması çok önemlidir. Sosyal hizmet uzmanı, mağdurun ve ailenin mahremiyet gereksinimine dikkat ederek bunu korumaya özen göstermelidir. 
Özetle Çocuk İzlem Merkezinde görevli sosyal hizmet uzmanları, aile ile ilk görüşme (gerektiğinde doğrudan mağdurla) yapar ve adli görüşme süreçlerinde aktif rol alarak mağdur ile ilgili alınacak tedbirler konusunda sosyal inceleme raporu hazırlar. Ayrıca, mağdur çocuğun yüksek yararı gözetilerek multidisipliner bir yaklaşımla yürütülen ekip çalışmasına profesyonelce katkı sağlar.

\section{SONUÇ}

Son yıllarda dünyanın birçok ülkesinde çocuğa yönelik cinsel istismar vakalarında artış olduğu belirlenmiştir. Örneğin, Amerika'da yılda her 50 çocuktan yaklaşık biri ölümcül olmayan cinsel inmal ve istismara uğramaktadır. Uzmanlara göre, her dört kız çocuğundan biri, her altı erkek çocuğundan biri 18 yaşından önce cinsel istismara uğramaktadır (Anonymous, 2012). Bu nedenle çocuğa yönelik cinsel istismarla mücadelede mağdur çocukların korunması, tespiti, tanısı, tedavisi ve rehabilitasyonu çok önemlidir.

Avrupa ülkeleri ve Amerika Birleşik Devletlerinde çocuğa yönelik cinsel istismarla mücadele kapsamında hemen hemen her çocuk hastanesinde çocuk koruma birimleri kurulmuştur. Bu birimlerin kuruluşu çok geçmişe dayanmasına karşın ülkemizde 10-15 yıllık bir geçmişe sahiptir. Ayrıca bu merkezlerin tamamı da üniversitelerin tıp fakültelerine bağlı çocuk hastanelerinde kurulmuştur. Sağlık Bakanlığı bünyesinde ise bu uygulama 2011 Ankara'da başlatılan pilot uygulama ile Çocuk İzlem Merkezi ile başlatılmıştır. Çocuk İzlem Merkezi, Sağlık Bakanlığı'na bağlı kuruluşlarda öncü bir merkez olması, cinsel istismar mağduru çocukların tıbbi ve psikiyatrik tedavilerinin yapılması, psiko-sosyal yönden desteklenmesi, adli sürecinin gizliliği açısından çok önemli bir merkezdir.

Çocuk cinsel istismarı konusunda önleme, tedavi ve izlemde etkin bir yaklaşım için ekip çalışmasına intiyaç vardır. Çünkü hiçbir hekim, savcı, polis, hakim, sosyal hizmet uzmanı, psikiyatrist, psikolog veya diğer disiplinlerdeki meslek elemanları tek başlarına bu sorun ile başedemez. Bu sorun ile mücadele, multidisipliner bir ekip çalışmasını gerektirmektedir.

2011 yılı Mayıs ayında Ankara'da pilot uygulamasına geçilen Çocuk İzleme Merkezlerinin sayısı gün geçtikçe artmaktadır. Ülkemizde çocuk istismarı ile etkin mücadele kapsamında Ankara, Adana, Antalya, Bursa, Diyarbakır, Gaziantep, İzmir, Kayseri ve Samsun'da olmak üzere toplam dokuz (9) Çocuk İzlem Merkezi aktif olarak hizmet vermektedir. Ayrıca Sağlık Bakanlığı 2013 yılında toplamda 
23 ilde 29 Çocuk İzlem Merkezinin açılmasını planlamaktadır (Habertürk, 2013). Bu merkezler ile çocukların bu süreçte örselenmesini en aza indirmeyi amaçlanmaktadır.

Ayrıca bu kapsamda, 4 Ekim 2012 Tarih ve 28431 sayılı Resmi Gazete'de Başbakanlık tarafından Çocuk İlem Merkezleri ile İlgili Genelge yayınlanmıştır. Bu genelgeye göre, çocuk istismarının önlenmesi ve istismara uğrayan çocuklara bilinçli ve etkin bir şekilde müdahale edilmesi amacıyla, öncelikli olarak cinsel istismara uğramış çocukların ikincil örselenmesini asgariye indirmek, adli ve tıbbi işlemlerin bu alanda eğitimli kişilerden oluşan bir merkezde ve tek seferde gerçekleştirilmesini temin etmek üzere; Sağlık Bakanlığı'na bağlı hastaneler/kurumlar bünyesinde Çocuk İzlem Merkezlerinin kurulması ve bu merkezlerin işleyişinin Sağlık Bakanlığı'nca koordine edilmesi gerekli görülmüştür. Aynı şekilde, zaman içerisinde ülke genelinde Çocuk İlem Merkezlerinin yaygınlaştırılması hedeflenmektedir.

Başbakanlık Genelgesi doğrultusunda Çocuk İzlem Merkezlerinin çalışma ve yaygınlaşma sürecinin sağlıklı ve amacına uygun bir şekilde yürütülmesi için gerekli tedbirleri görüşüp karara bağlamak ve bu konuda kurumlararası işbirliği ve koordinasyonu sağlamak üzere; Sağlık Bakanlığı Müsteşarı veya yardımcısının başkanlığında; Adalet Bakanlığı, Aile ve Sosyal Politikalar Bakanlığı, İçişleri Bakanlığı, Milli Eğitim Bakanlığı, Diyanet İşleri Başkanlığı ve Adli Tıp Kurumu Başkanlığı temsilcilerinin (bakanlıklardan müsteşar yardımcısı, başkanlıklardan başkan yardımcısı düzeyinde) katılımıyla Çocuk izlem Merkezi Yönetim ve Koordinasyon Kurulu oluşturulmuştur. Kurul tarafından alınan 22/10/2012 tarihli ve 2012/1 sayılı kararla çocuk izlem merkezlerinin çalışma usul ve esaslarına ilişkin esaslar belirlenmiştir (HSYK, 2013). Aynı şekilde, Hâkimler ve Savcılar Yüksek Kurulunca yayımlanan "Soruşturma Usul ve Esasları" konulu genelgeye göre soruşturmaların etkinliğinin sağlanması için işlemlerin bu genelge doğrultusunda yapılması gereği vurgulanmıştır.

Çocuk İzlem Merkezi sayısının artması ve yapılacak hizmetiçi eğitimler, çocuk istismarının tanımını yapabilme, çocuk istismarının boyutunu ve önemini kavrama, istismara uğrayan çocuğu fark edebilme konularında sağlık personelinin daha duyarlı olmasını sağlayacaktır. Bu sayede de cinsel istismara uğradığı fark edilen, öğrenilen ya da şüphe uyandıran çocukların Çocuk İzlem Merkezine bildirimlerinin artacağı düşünülmektedir. 
Çocuk İzlem Merkezi yargılama sürecini hızlandırmakta, süresini kısaltmakta, adli soruşturmanın ilgili uzmanlar tarafından yürütülmesini sağlamakta, soruşturmanın her aşamasında mağdurun yeniden mağdur edilmemesi açısından önemli bir işlevi gerçekleştirmektedir. Bu bakımdan bu uygulama insan haklarına verilen değerin bir göstergesidir.

Cinsel istismardan çocukları korumak amacıyla, toplumda hassasiyet yaratacak eğitim kampanyalarının başlatılması ve bu sayede farkındalık yaratılarak, ailelerin, öğretmenlerin ve çocukların davranışlarını olumlu yönde değiştirmek amacıyla gerekli çalışmalar hem kamu, hem de sivil toplum kuruluşları tarafından yapılmalıdır.

Çocuk izlem Merkezlerinde yürütülen sosyal hizmet uygulamasını güçlendirmek için yeterli sayıda sosyal hizmet uzmanı görevlendirilmeli, sosyal hizmet stajyerleri için uygulama alanı kapsamına alınmalı ve bu alanda bilimsel araştırmalar yapılmalıdır.

Ayrıca bu konuda bir rehber hazırlanmalıdır. Bu rehberde, alanda çalışan veya çalışacak olan sosyal hizmet uzmanlarını mesleki müdahalelerinde cinsel istismar mağduru çocuk ve ailesi ile çalışırken hangi teknik ve yöntemleri kullanacakları konusu detaylı bir şekilde ortaya konulmalıdır. Aynı şekilde bu alanda çalışan ve bundan sonra da çalışacak olan sosyal hizmet uzmanlarının daha donanımlı hale gelmeleri için aile danışmanlığı eğitimleri almalarının faydalı olacağı düşünülmektedir.

Daha önce bu alanda çalışan sosyal hizmet uzmanlarının deneyimlerinden ve akademik faaliyetlerinden de yararlanılmalıdır. Sağlık Bakanlığı'nın Çocuk İzlem Merkezlerini açmış olması ve bunun sayısını günden güne arttırması önemli bir gelişmedir. Ayrıca sağlık alanında sosyal hizmet uzmanlarına istihdam yaratacak olması açısından da önemli bir gelişmedir. 


\section{KAYNAKLAR}

Anonymous, (2012). Children's Health Care of Atlanta, http://www.choa.org/Childrens Hospital-Services/ChildProtection-Center/About-the-Child-Protection-Center, Erişim Tarihi, 14.09.2012.

Beyazova, U. ve Şahin. F. (2007). Çocuk istismarı ve inmaline yaklaşımda hastane çocuk koruma birimleri. Türk Pediatri, 42. Özel Sayı: 16-88.

Browne, A. ve Finkelhor, D. (1986). Impact of child sexual abuse. Psychol Bull, 99, 66-77.

Butcahart, A. ve Harvey, A.P. (2006). World Health Organization and International Society for Prevention Of Child Abuse and Neglect, Preventing Child Maltreatment : A guide to taking and generation evidence. WHO Pres, Geneva, Switzerland, 10.

Canat, S. (1994). Ergenlerde aile içi taciz. Çocuk ve Gençlik Ruh Sağlığı Dergisi, 1, 18-22.

Çì (Çocuk İzlem Merkezi). (2011), Çocuk cinsel istismarı eğitici eğitimi, ders not ve sunumları.

Çocuk İzlem Merkezi Yönetim Ve Koordinasyon Kurulu, (2012). 22.10.2012 tarih ve 2012/1 sayılı toplantı karar tutanağı, http://www.hsyk.gov.tr/Mevzuat/Duyurular/cocuk-izlem-merk-cimkoord-topl-tutnk.pdf, erişim tarihi: 01.04.2013.

Çocuk Koruma Kanunu (2005). Resmi Gazete, 15.07.2005 tarih, 25876 sayı ve 5395 sayılı kanun.

Dağlı, E. Tolga ve İnanıcı, M.A. (2010). Üniversiteler için hastane temelli çocuk koruma merkezleri el kitabı. Fersa Ofset Matbaacılık, Ankara.

Ferguson, D.M., Horwood, L.J. ve Lynskey, MT. (1997). Childhood sexual abuse, adolescent sexual behaviors and sexual revictimization. Child Abuse Neglect, 21, 789-803.

Green, A. (1996). Child sexual abuse and incest. Child and Adolescent Psychiatry a Comprehensive Textbook, 2end Edition. Baltimore, MA: Williams and Wilkins, In: Lewis Med. : 1041-1048.

Habertürk, (2013). İnternet sayfası, erişim tarihi: 01.04.2013 http://www.haberturk.com/saglik/haber/795874-saglik-bakaniacikladi 
Hancı, H. (2002). Adli tıp ve adli tıp bilimler. Seçkin Yayıncılık, Ankara, 265-270.

HSYK (Hakimler ve Savcılar Yüksek Kurulu), (2013). Resmi internet sayfası, erişim tarihi, http://www.hsyk.gov.tr/Mevzuat/Duyurular/cocuk-izlem-merkezi.pdf

Kara, B., Biçer. Ü. ve Gökalp. A.S. (2004). Çocuk istismarı. Çocuk Sağlığı ve Hastalıkları Dergisi, 47, 140-151.

Kendall-Tackett, K.A., Williams, L.M., Finkelhor, D. (1993) Impact of sexual abuse on children. Psychol Bull,113, 164-180.

Kerimoğlu, E. ve Avcı, A. (1991). Ailede cinsel kötü kullanım ve kardeşler arasında cinsel oyun. 27. Ulusal Psikiyatrik Bilimler Kongresi Özet Kitabı, 90, Antalya.

Koşar, N. G. (1989). Sosyal hizmetlerde aile ve çocuk refahı alanı. Yargıçoğlu Matbaası, Ankara.

Kurtay, D., Özkök S., Barlık Y., Yatağan, M., Kurtay, A., Akman. E. (2004). Çocuk inmal ve istismarına multidispner yaklaşım. T.C. Başbakanlık Sosyal Hizmetler ve Çocuk Esirgeme Kurumu, Aydın.

Polat, O. (2006). Cinsel istismar rehberi. Forart Matbaa, İstanbul, 10-70.

Putnam, F.W. (2003). Ten year research update review: child sexual abuse. Journal of American Academy, Child Adolesc Psychiatry, 42, 269-78.

Smith, M. ve Bentovim, A. (1994). Sexual abuse. Child And Adolescent Psychiatry-Modern Approaches, Blacwell Science, 230-251.

Taner, Y. ve Gökler, B. (2004). Çocuk istismar ve inmali: psikiyatri yönleri. Hacettepe Tıp Dergisi, 35, 82-86.

TCK (5237 Sayılı Türk Ceza Kanunu), (2005). 12.10.2004 tarih ve 25611 sayılı Resmi Gazete.

Yurdakök, K. (2010). Çocuk istismar ve inmali, tanımı ve risk faktörleri. Katkı Pediatri Dergisi, 32 (4), 423 - 434. 